\title{
Z NIE OPUBLIKOWANYCH WSPOMNIEŃ Z (NIE TYLKO) EMIGRACYJNEGO ŻYCIA KOMPOZYTORA ROMANA PALESTRA
}

\author{
Tadeusz WYRWA (Paryż)
}

Na wstępie kilka biograficznych danych wybitnego, ale ciagle mało znanego kompozytora, którego różne koleje losu odzwierciedlają warunki i atmosferę w jakiej pracowali twórcy wspólnej nam wszystkim kultury.

Roman Palester (1907-1989) studiował na Uniwersytecie Warszawskim i w Konserwatorium w Warszawie, które ukończył w 1931. Brał aktywny udział w życiu muzycznym. Lata wojenne spędził przede wszystkim w Warszawie. Po wojnie zamieszkał w Krakowie, gdzie przez jakiś czas wykładał kompozycję w Akademii Muzycznej uczestnicząc jednocześnie w pracach Międzynarodowego Towarzystwa Muzyki Współczesnej. Był to okres, kiedy jego muzykę często można było słyszeć na estradach koncertowych zarówno w Polsce, jak i za granicą.

W 1947 roku wyjechał, wraz z żoną Barbarą, do Paryża. Celem jego wyjazdu nie była emigracja, lecz oderwanie się od krajowego zgiełku, żeby móc skoncentrować się wyłącznie na kompozycji. W dalszym ciagu utrzymywał ścisły kontakt z krajowymi ośrodkami muzyki polskiej. W 1948 roku odmówił udziału w Światowym Kongresie Intelektualistów w „Obronie Pokoju”, jaki odbył się we Wrocławiu, ale rok później, czyli w 1949, był obecny na Ogólnopolskim Zjeździe Kompozytorów i Krytyków Muzycznych.

Pogarszająca się sytuacja w Polsce i trudności zachowania godnej postawy — a był to okres srożącego się coraz bardziej stalinizmu — był powodem, że w 1950 roku Palester wybrał emigrację. W Paryżu znalazł się w ciężkiej sytuacji tak pod względem zawodowym, jak i materialnym. Były to najtrudniejsze lata w życiu Palestra, a i wcześniejsze nie były łatwe. Wartościowym z tej dziedziny przyczynkiem jest koresponden- 
cja, którą Palester utrzymywał z Kazimierzem Wierzyńskim, jaka znajduje się w Bibliotece Polskiej w Paryżu ${ }^{1}$.

$$
* * *
$$

W okresie, z którego zachowała się ta korespondencja, Wierzyński mieszkał w USA i tam na jego adres Palester wysyłał listy. Jakiś czas przebywał w Londynie, skąd w liście z dnia 6 sierpnia 1946 wyrażał Wierzyńskiemu wdzięczność za przysłaną książkę, nie podając jej tytułu. Chodziło zapewne o Krzyże i miecze wydane w Londynie w 1946 („Krzyż” — znak męczeństwa i „miecz” — znak sprawiedliwości Bożej). Palester dziękując, w bardzo serdecznych słowach pisze, iż jest głęboko wstrząśnięty sposobem i tonem, w jakich Wierzyński „daje świadectwo wszystkich klęsk polskich naszego pokolenia". Jednocześnie przesyłał czułe pozdrowienia od wielu innych rodaków, którzy żyjąc w różnych warunkach obcować będą z jego poezją.

Żyjemy zaiste - pisał następnie — w czasach „Wielkiej Samotności”, kiedy istotne i najgłębsze rzeczy dokonują się w „najdalszym i największym oderwaniu od swojej gleby i swego «klimatu»".

Jednocześnie Palester informował Wierzyńskiego, że za parę dni wraca z żoną do Polski i wyraża nadzieję, że jesienią może uda mu się pojechać do Paryża. Z pobytu w Londynie był zadowolony, ale nie widział tam możliwości zahaczenia się na jakiś czas.

Kilka miesięcy później, w liście z Paryża, z 9 stycznia 1947, Palester donosił, że wraz z żoną wyrwali się na krótko do francuskiej stolicy. Nie mając potwierdzenia odbioru wyżej wspomnianego listu, jaki wysłał z Londynu, Palester pisał, że na wypadek, gdyby Wierzyński go nie otrzymał, to teraz pragnie ponownie wyrazić poecie wdzięczność za jakże głębokie i bez reszty wypowiedzenie tego wszystkiego „co nam tak bardzo leży na sercu”. Jednocześnie potwierdzał, że wyjazdy za granicę stają się coraz trudniejsze. Dlatego też wraz z żoną postanowił wyrwać się raz jeszcze na Zachód, żeby próbować szukać gdzie indziej „Pastwiska”. Zaznaczał jednak, że we Francji nie ma dużych możliwości. Dlatego też byłby Wierzyńskiemu bardzo wdzięczny za poinformowanie go, czy byłyby jakieś możliwości zahaczenia się w USA. Zapytuje więc, czy w ogóle kompozytor muzyki poważnej ma szansę dania sobie tam rady i czy mógłby liczyć na poparcie Polonii amerykańskiej, no i najistotniejsze: czy wpuszczono by ich do Stanów?

Odwrotną pocztą Wierzyński poinformował Palestra o sytuacji. Z kolei, bezzwłocznie również, dziękując za wiadomości, Palester pisał w liście z Paryża, z datą 3 lutego 1947 roku, że wiadomości te przedstawiają smutny obraz rzeczywistości. Nie oczekiwał cudów i był raczej nastawiony na ciężkie przeprawy natury zarówno moralnej, jak i materialnej, ale co go przejęło najwięcej, „to poczucie jakiegoś zagubienia, zatopienia w nicości setek tysięcy najlepszych istnień polskich”. Palester przypuszczał, że ,życie emigracji choćby najcięższe ma w sumie nie tylko jakieś znamię wielkości... ale daje też maximum realnych, konkretnych osiągnięć organizacyjnych". Przytacza konkretny przykład: zaproponował Czapskiemu, żeby 2. Korpus zaczął wydawać również muzykę polską, aby „ruszyć jakoś z miejsca bardzo rozbałaganioną działalność muzyczną na emigracji”. Józef Czapski jednak, mimo najlepszych jego chęci, nic w tej

\footnotetext{
${ }^{1}$ Listy Romana Palestra do Kazimierza Wierzyńskiego z lat 1946-1955 — Biblioteka Polska W Paryżu (zbiory nieopracowane, nr akcesji 7221/1-2). Wszystkie kolejne cytaty $\mathrm{z}$ korespondencji pochodzą $\mathrm{z}$ tego zbioru.
} 
sprawie nie mógł zrobić, bo „nie ma funduszów, nie ma możliwości i — jak się zdaje — nie ma dla kogo. A to ostatnie oczywiście najsmutniejsze ze wszystkiego".

W liście z 28 marca 1947 roku Palester pisał, że nie ma właściwie nic nowego do zakomunikowania, nadmieniając że nadal są na przedłużonych paszportach i nadal trudno im jest cokolwiek decydować, a to głównie z powodu natury materialnej. „Londyńskie kontakty bez rezultatu i raczej deprymujące, szczególnie jeśli chodzi o dziedzinę kulturalną. Ano trudno, trzeba się przebijać dalej”. W podobnym nastroju donosił w liście z 11 maja 1947, że w dalszym ciagu pragneliby nie wracać do Polski, no i oczywiście móc się spotkać w Paryżu bądź w USA. Na razie, wyznawał dalej

[...] nasza sytuacja paryska jest o tyle pożałowania godna że jesteśmy — oby tylko chwilowo - w ostatniej nędzy i w wielkiej ,panice” finansowej a nie wolno nam tego okazywać bo wtedy przecież od razu mi powiedzą: „A czemu pan nie wraca do kraju, gdzie pan zawsze może z największą łatwością zarobić”.

Palester wyznaje, że znajdują się w sytuacji tragikomicznej, która na dłuższą metę jest niemożliwa do utrzymania, ,a bardzo pragnęlibyśmy uniknąć powrotu do kraju”.

Miesiąc później, w liście z Paryża z dnia 6 czerwca 1947, Palester serdecznie dziękował Wierzyńskiemu za jego starania, aby pomóc mu w trudnej sytuacji, w jakiej się znajdował. Nadmieniał, że chętnie wybrałby się do USA chociażby na jakiś krótki tylko czas. Ubolewał nad pogarszającym się stanem rzeczy w Europie Zachodniej, co jest skutkiem wkroczenia w jakąs ponurą epokę, „,w której to wszystko co robimy, traci coraz bardziej jakikolwiek sens".

W lecie 1947 roku Palester był w Polsce, po powrocie do Paryża, w liście z 28 września pisał, że pobyt w kraju bardzo go zmęczył i że nie zaprzestał starań o zostanie na Zachodzie, najlepiej byłoby dostać się do Stanów. Przypomina jednak, że to ,pozostanie" na Zachodzie w dużej mierze uzależnione jest od możliwości utrzymania się, a z tym jest tutaj bardzo trudno. Jakoś dawali sobie radę, ale w rezultacie „przy takim życiu z tygodnia na tydzień ciagle staje przed nami ewentualność konieczności powrotu do kraju gdy tylko jakakolwiek z dorywczych spraw finansowych nie wypali”. Nie wyklucza przeto powrotu do Polski, ,ze względów czysto materialnych, zdając sobie zresztą całkowicie sprawę z całego tragizmu i beznadziejności takiego powrotu”.

W korespondencji z Wierzyńskim nastapiła długa przerwa, bo następny list Palestra, wysłany z Paryża, nosi datę 9 sierpnia 1950 roku. W liście tym autor przeprasza za długie milczenie i obszerniej pisze o swoich losach od roku 1947. Był to okres ich życia, „który zbyt często już graniczył ze skrajną nędzą, ale ostatecznie udało się nam przetrwać i artystycznie ten okres był dla mnie bardzo korzystny”. Następnie pisze, że na skutek nacisku kolegów krajowych, jak również z porady niektórych „emigrantów”, początkowo nie zrywał stosunków z krajem. Na dłuższą jednak metę trudno było tę sytuację wytrzymać „i w ciagu bieżącego roku definitywnie zerwałem wszystkie stosunki”.

Następnie Palester ubolewa nad tym, że w kraju odbywa się planowe „wykańczanie" tego wszystkiego, co do niedawna uważane było za najpiękniejsze cechy kultury polskiej. Autor pisze, że w obronie wartości tej kultury „trzeba zaczą́ wielki krzyk”. Jest zdania, że polska prasa emigracyjna nie docenia groźby tej sytuacji,

[...] która jest montowana tak niesłychanie zgrabnie, że jeżeli potrwa lat kilkanaście to po prostu nie trzeba będzie ,włączać” się do ZSSR, bo wtedy Polacy w Polsce przestaną „,być Polakami” w sensie jakiejś elementarnej odrębności kulturalnej.

W dalszym ciągu listu Palester pisze, że nie jest tutaj (w Paryżu) związany z żadnym stronnictwem politycznym, widuje ludzi zarówno spod znaku Mikołajczyka, jak i środowiska londyńskiego. U jednych i u drugich dostrzega prymat zagadnień poli- 
tycznych przy jednoczesnym braku odpowiedniego zrozumienia dla spraw, jakie politykom wydają się drugorzędne, ale które w rzeczywistości „są sprawami życia i śmierci i to już nie tylko nawet dla samych Polaków".

Sytuacja, w jakiej znajdował się wówczas Palester, była katastrofalna. W tym samym liście, o którym wyżej jest mowa, autor pisze, że ostatnie miesiące jakoś jeszcze wytrwał, ale nie ma pojęcia co będzie dalej, bo wszystko się kończy i nie mogą z żoną znaleźć żadnej pracy, „bo jak Pan wie, przyjaźń i życzliwość francuska kończy się w momencie, kiedy człowiek czegoś potrzebuje". Wtedy też dowiedział się o powołaniu do życia Komitetu Wolnej Europy (Free Europe Committee). Zwracał się przeto do Wierzyńskiego z prośbą o informacje (i ewentualne poparcie), czy byłoby możliwe nawiązanie z tym komitetem jakiejś formy współpracy. Wyjaśniał jednak, że „nie chce pomocy w sensie zapomogi pieniężnej”.

Palester z naciskiem podkreślał, że chodzi o współpracę, do której, jak wiadomo, doszło i w 1952 rozpoczął prace jako kierownik działu kulturalnego w Radiu Wolna Europa w Monachium, gdzie prowadził audycje poświęcone wydarzeniom kulturalnym na Zachodzie i organizował dyskusje na temat polskich książek, polemizując z zasadami upolitycznionej etyki socrealistycznej. Po przejściu na emeryturę w 1972 roku Palester zamieszkał ponownie w Paryżu, oddając się całkowicie pracy kompozytorskiej.

Przez wiele lat, zarówno w okresie stalinizmu jak i późniejszym, cały dorobek Palestra znajdował się na indeksie. Odebrano nawet Palestrowi członkostwo Związku Kompozytorów Polskich. Jednocześnie, wyrażano wtedy nadzieję, że „historia zaliczy jego twórczość do szczytowych osiągnięć muzyki polskiej i nada jego dziełu walor ponadczasowy"2. Kilkanaście lat później, inny z kolei autor sygnalizował: „potrzeba «odkrycia» muzyki Romana Palestra i nadania jej rangi pierwszorzędnego czynnika polskiego dorobku muzycznego naszego $[X X]$ stulecia jest dziś w pełni zrozumiana...”. Nie miano wątpliwości, że „muzyka Palestra czeka estradowego i scenicznego odkrycia"3. I ciągle właściwie czeka...

Palester zmarł w 1989 roku w Paryżu. W pośmiertnym o nim artykule, pióra Jacka K. Machniewicza, autor pisał, że Palester był ,polskim patriotą w najgłębszym tego słowa znaczeniu i nie-konformistą w najszerszym pojęciu”. Przeciwstawiał się reglamentacji kultury, walczył o „wolność sztuki i o integralność polskiej kultury”. Autor dodawał, że od nie tak dawna zaczęto w Polsce mówić o „renesansie” Palestra i miał nadzieję, że ,śmierć kompozytora zbytnio nie opóźni klasyfikacji i publikacji jego utworów, zaś przez Polskę chyba trafią za granicę, gdzie zajmą należne miejsce w światowej literaturze"4. Jak dotychczas, niestety, miejsce to nadal nie jest należycie zajęte i to zarówno w literaturze krajowej, jak i światowej. Jeden przykład więcej naszego przede wszystkim zaniedbania.

$$
* * *
$$

Celowość i motywację walki o wolność sztuki i nauki Palester dobitnie zademonstrował historycznym szkicem pt. Konflikt Marsjasza, który ukazał się w 1951 roku na łamach paryskiej „Kultury”. . Punktem wyjścia tego szkicu jest zwrócenie uwagi na ulegającą, od starożytności do współczesności, zmianę interpretacji pojęcia wolności

\footnotetext{
2 J. Gajek, Muzyka Romana Palestra, Kultura 1966 nr 10(228), s 106.

${ }^{3}$ A. Sutkowski, O twórczości Romana Palestra, Kultura 1978 nr 7/8(370/371), s. 180, 186.

${ }^{4}$ Zob.: J. K. Machniewicz, Ci co odeszli: Roman Palester, Kultura 1989 nr 10(505), s. 134-137.

${ }^{5}$ R. Palester, Konflikt Marsjasza, Kultura 1951 nr 7/8(45/46), s. 3-16.
} 
i godności człowieka. W powszechnym dziś zamieszaniu, sprawą szczególnej wagi jest „dla kogo się pisze”. A często, pisze się „na zamówienie społeczne”. Pod wieloma względami argumentacja tego stanu rzeczy jest ciągle, jeżeli nie identyczna, to zbliżona do materialistycznego urządzenia świata w oparciu o „naukowe” i „rzeczowe” metody. $\mathrm{Z}$ dużym hukiem rzucono przeto hasło zburzenia starej cywilizacji, wywodzącej się ze spirytualistycznej i humanistycznej koncepcji i na jej gruzach zbudowanie nowej, pochodzącej z nowych, diametralnie odmiennych przesłanek.

Palester pisze, że mówi się powszechnie o żelaznej kurtynie, jako o magicznej linii dwu odrębnych światów dzielących ludzi na zwolenników jednego lub drugiego świata — w zależności od ich miejsca zamieszkania. Otóż przywódcy i różni „ideolodzy” ozdabiają to wszystko wzniosłymi frazesami odnoszącymi się do wolności, pokoju, sprawiedliwości ,zapominając, jak bardzo przyczynili się sami do zdyskredytowania wartości tych pojęć”. Następnie podkreśla, że kryzys moralny przebiega podobnie po obu stronach żelaznej kurtyny. Walka o uratowanie podstawowych wartości naszej cywilizacji toczy się wszędzie, z tym, że otwarta walka toczyć się może tylko na Zachodzie a nie za żelazną kurtyną, gdzie miliony ludzie oddano w niewolę wrogiego im systemu, który metodycznie dążył do zbudowania „nowej, socjalistycznej kultury”. Jaką np. wartość może mieć chełpienie się wielką liczbą młodzieży chłopskiej i robotniczej na uniwersytetach, jeżeli celem tych uniwersytetów jest uformowanie umysłów całkowicie bezkrytycznych? Chodziło przecież o przewartościowanie wszystkiego i ,zburzenie własnymi rękami aż do podstaw tego, co było dla nas dotychczas cenne i konieczne do życia”.

Z upływem czasu ostrze oporu tępiało; w tym straszliwym kieracie „łamią się charaktery, gną karki”. W wytworzonej sytuacji „każdy musi w sposób najzupełniej osobisty i na swoją odpowiedzialność zdecydować o swej dalszej drodze”. W Polsce, o czym pisze dalej ze smutkiem Palester, znajdują się obecnie artyści (i w ogóle pisarze), którzy poszli na lep urzędowej propagandy i za pieniądze robią, co im się każe. Ale sa i tacy, którzy nie poszli na żadne ustępstwa, zachowali dotychczas uczciwość artystyczną i wybrali - milczenie. Oczywiście nie brak też jest grafomanów, dla których otworzyły się olśniewające możliwości. Faktem jest, że panuje tam duch kliki, stosunki, przyjaźnie i lizusostwo, co w sumie przyczynia się do ogólnej demoralizacji. Każdy jednak, zły czy dobry, twórca czy grafoman, musi stale kłamać, aby „utrzymać się na powierzchni”. Dokąd jednak można żyć w absolutnym kłamstwie i na każdym kroku kłamać i słuchać kłamstwa? Przy końcu swojego szkicu Palester zwraca się do bliżej nieokreślonego przyjaciela-artysty, który pyta co robić, zostać w kraju czy wybrać wygnanie? W odpowiedzi Palester pisze: cóż można w danym wypadku powiedzieć, jeśli samemu uniknęło się cierpienia będąc poza krajem? Najważniejsze jest, „nie sprzeniewierzyć się temu, co uważamy za pierwszy obowiązek nas wszystkich, to jest naszej uczciwości artystycznej. Nie to jest ważne gdzie ten obowiązek wykonamy łatwiej, ale gdzie go wykonamy" i nadto — dodajmy od siebie — jak go wykonamy? 